\title{
Telewerken als hulpbron? 'Flow' en uitputting onder twee telewerkcategorieën vergeleken
}

\author{
Pascale Peters en Marijn Wildenbeest*
}

Deze cross-sectionele studie onder 331 telewerkers onderzoekt de relatie tussen de mate van telewerken enerzijds ('substantieel' versus 'marginaal') en 'flow' en uitputting in het werk anderzijds. Naar analogie van het Job demands-resources-model werd substantieel telewerken beschouwd als een hulpbron in het werk, die werknemers meer tijd en ruimte biedt voor reflectie en herstel dan marginaal telewerken. Met behulp van multivariate (regressie)analyses werden zowel directe als moderatie-effecten tussen de mate van telewerken en de twee uitkomstvariabelen onderzocht. Empirische steun werd gevonden voor de veronderstelling dat substantiële telewerkers vaker 'flow' ervaren dan marginale telewerkers. Opvallend genoeg ervoeren substantiële telewerkers meer 'flow' wanneer zij meer afleiding op de thuiswerkplek ondervonden. Werknemers die frequenter overwerkten en werknemers die meer autonomie in het werk rapporteerden, ervoeren minder uitputting wanneer zij substantieel telewerkten dan wanneer zij marginaal telewerkten. Geconcludeerd wordt dat substantieel telewerken alleen onder sommige condities als hulpbron kan worden beschouwd.

Trefwoorden: telewerken, Het Nieuwe Werken, hulpbron, flow, uitputting

\section{Inleiding ${ }^{1}$}

1.1 Hernieuwde aandacht voor telewerken

Tele(thuis)werken (in deze studie kortweg 'telewerken' genoemd) is een innovatieve manier van werken waarbij werknemers, met behulp van informatie- en communicatietechnologie (ICT), werkzaamheden, die normaal gesproken op een centrale

* Pascale Peters is als universitair docent Strategisch Personeelsmanagement verbonden aan The Institute for Management Research, Radboud Universiteit Nijmegen. Correspondentieadres: Institute for Management Research, Departement Bedrijfskunde, Radboud Universiteit Nijmegen, Postbus 9108, 6500 HK Nijmegen, tel. 024-3611856, e-mail: p.peters@fm.ru.nl

Marijn Wildenbeest was ten tijde van het onderzoek als master student verbonden aan dezelfde universiteit. 
werklocatie (op kantoor) worden verricht, op afstand van de werkgever of opdrachtgever (thuis) uitvoeren (Gajendran \& Harrison, 2007). Meestal gaat het om werknemers die minstens één dag in de week op afstand (thuis)werken (Gareis, 2003).

Begin jaren zeventig van de vorige eeuw werd het telewerkconcept voor het eerst in de Verenigde Staten onder het label 'telecommuting' geïntroduceerd als reactie op de oliecrisis en de verkeers- en milieuproblematiek (Nilles, 1998; Kurland \& Bailey, 1999). Tijdens de economische crisis van de jaren tachtig werd telewerken vooral gezien als een strategie voor organisaties om overheadkosten te besparen. Eind jaren negentig werd telewerken, onder druk van de krappe arbeidsmarkt, vooral ingezet door organisaties om tegemoet te komen aan de vraag onder hoogopgeleide 'professionals' naar meer autonomie en flexibiliteit in het werk. In de periode van economische neergang die daarop volgde, verslapte de aandacht voor telewerken (Van Klaveren, Tijdens, Peters \& Wetzels, 2005).

98 Sinds een aantal jaren leiden de sterk toegenomen concurrentie, de krapte op de arbeidsmarkt, de noodzaak voor organisaties om in de huidige kenniseconomie te blijven innoveren, maar ook de huidige economische crisis, tot hernieuwde aandacht voor telewerken, ook onder werkgevers en beleidsmakers in Nederland. Zo verwacht de Taskforce Mobiliteitsmanagement (2008) dat met het stimuleren van telewerken de verkeerscongestie, in het bijzonder het woon-werkverkeer, kan worden teruggedrongen. Hierdoor zou de bereikbaarheid en efficiëntie van bedrijven aanzienlijk kunnen worden vergroot. Pleitbezorgers van telewerken stellen dat het opnemen van telewerken in de werkroutines van organisaties, vaak in combinatie met nieuwe managementprincipes en werkplekinnovaties (Peters, Den Dulk \& Van der Lippe, 2009), zelfs bepalend is voor 'onze concurrentiekracht in een globaliserende economie' (www.telewerkforum.nl). Onder het credo 'Het Nieuwe Werken'worden werknemers gestimuleerd om 'op afstand te werken', en om hun werkzaamheden zelf te organiseren, verantwoordelijkheid te nemen, innovatief gedrag te tonen, en daardoor tot creatieve oplossingen te komen voor problemen in het werk (Kumar, 200o; www.telewerkforum. nl). Bekende voorbeelden van organisaties die 'Het Nieuwe Werken'(recentelijk) hebben ingevoerd zijn Interpolis, Microsoft, IBM en Rabobank Nederland.

\subsection{Telewerken als hulpbron}

Het voorgaande laat zien dat de voordelen van telewerken voor individuele werknemers steeds meer aandacht krijgen in het telewerkdebat. Telewerken wordt daarbij niet alleen gezien als een middel om de werk-privébalans van werknemers te verbeteren (Peters \& Van der Lippe, 2007a), maar ook om hun prestaties en arbeidstevredenheid te verhogen (Gajendran \& Harrison, 2007). Vanuit beide gezichtspunten kan telewerken worden gezien als een hulpbron in het werk (Peters \& Van der Lippe, 2007a). Volgens het Job demands-resources-model zijn hulpbronnen functioneel voor het behalen van werkgerelateerde doelen en kunnen ze de persoonlijke groei en ontwikkeling van werknemers stimuleren (Bakker \& Demerouti, 2007). Daarnaast zouden hulpbronnen ook stressoren en de daarbij behorende psychologische en fysieke kosten het hoofd kunnen bieden ('bufferhypothese') én het effect van andere hulpbronnen kunnen versterken ('versterkingshypothese') (Van Ruysseveldt, Smulders \& Taverniers, 2008). Wanneer telewerken als hulpbron wordt gezien, valt een positieve relatie tussen telewerken en positieve werkuitkomsten te verwachten. 
De relatie tussen telewerken en positieve werkuitkomsten zal naar verwachting echter afhangen van de mate waarin werknemers telewerken (Bailey \& Kurland, 2002). De mate waarin werknemers telewerken vormt echter vaak een bron van discussie binnen organisaties. Ondanks de in de literatuur naar voren gebrachte voordelen van telewerken staan lang niet alle organisaties hier positief tegenover. Hoewel managers niet altijd onwelwillend zijn, staan veel direct-leidinggevenden hun werknemers liever toe om 'af en toe' dan structureel en substantieel te telewerken. Telewerken wordt vaak ad hoc toegestaan, bijvoorbeeld wanneer deadlines moeten worden gehaald (Peters, Den Dulk \& De Ruijter, 20Io). Ook wanneer een organisatie een formeel telewerkbeleid heeft geïntroduceerd, of wanneer functies van werknemers in theorie 'telewerkbaar' zijn (Van Klaveren et al., 2005), is het niet vanzelfsprekend dat directleidinggevenden telewerken accepteren als een geïnstitutionaliseerde praktijk in hun eigen afdeling (Peters et al., 20IO).

Cijfers van de vakbond FNV laten zien dat telewerken in de meeste gevallen beperkt blijft tot een marginale praktijk: in 2007 telewerkte $32 \%$ van de gehele Nederlandse werkende beroepsbevolking (inclusief thuiswerkende zzp'ers) minstens één uur per week. Tegenover de $14 \%$ die substantieel, ofwel - één dag per week of meer - vanuit huis werkte, werkte I $8 \%$ marginaal, ofwel minder dan één dag per week vanuit huis (Beffers \& Van den Brink, 2008). Wanneer telewerkcijfers door de tijd heen worden vergeleken, blijkt de hernieuwde aandacht voor telewerken in de praktijk vooral samen te gaan met een groei van het percentage marginale telewerkers (Peters \& Heusinkveld, 2008; Gareis, 2003). De vraag is echter of 'marginaal telewerken' en 'substantieel telewerken' in gelijke mate samengaan met positieve werkuitkomsten.

\subsection{De onderhavige studie}

Doel van de onderhavige studie is om inzicht te verkrijgen in de relatie tussen de mate van telewerken en twee positieve werkuitkomsten: meer 'flow' en minder uitputting in het werk. In deze bijdrage gaat de aandacht uit naar de groep werknemers die regelmatig telewerkt, maar in verschillende mate. De centrale vraag is of werknemers die substantieel telewerken (één dag per week of meer) vaker 'flow' en minder uitputting ervaren dan werknemers die marginaal telewerken (minder dan één dag per week). Naast het analyseren van de directe relatie tussen de mate van telewerken en 'flow' en uitputting, wordt nagegaan of substantieel telewerken (beschouwd als hulpbron) bepaalde stressoren meer buffert, ofwel het hoofd kan bieden, dan marginaal telewerken. Tevens wordt onderzocht of de samenhang tussen andere hulpbronnen enerzijds, en 'flow' en uitputting anderzijds, sterker is wanneer werknemers substantieel telewerken dan wanneer zij marginaal telewerken. In het hierna volgende wordt een voorlopig antwoord op bovenstaande vragen geformuleerd in de vorm van een zevental hypothesen.

Flow

In de literatuur wordt 'flow' gezien als een kortstondige piekervaring tijdens het werk, gekenmerkt door absorptie, werkplezier en intrinsieke motivatie (Scheeres \& Bakker, 2003). Absorptie verwijst naar een mentale conditie van opperste concentratie, waarbij mensen volledig in hun werk opgaan. Mensen die werkplezier ervaren, oordelen positief over de kwaliteit van hun arbeidsleven. Intrinsieke motivatie betreft de wens om een 
bepaalde activiteit uit te voeren met als doel het ervaren van plezier en bevrediging die inherent zijn aan die activiteit zelf. Mensen die intrinsiek gemotiveerd zijn, zijn voortdurend geïnteresseerd in hun eigen bezigheden. Dit zorgt ervoor dat men langer met de activiteit wil doorgaan. Werknemers ervaren meer 'flow' in hun werk wanneer zoveel mogelijk aan alle drie voorgenoemde voorwaarden is voldaan (Bakker, 2008). Na afloop van een 'flow'-ervaring voelt men zich gelukkig en voldaan (Csikszentmihalyi, I992). Voor veel werknemers speelt het verwachte voordeel van geconcentreerder en efficiënter kunnen werken in de thuisomgeving een belangrijke rol bij hun keuze voor telewerken (Bailey \& Kurland, 2002; Fouarge, Grim, Kerkhofs, Roman \& Wilthagen, 2004; Peters, Tijdens \& Wetzels, 2004; Beffers \& Van den Brink, 2008). Door de hogere telewerkfrequentie zal substantieel telewerken, in vergelijking met marginaal telewerken, waarschijnlijk positief met de drie bovengenoemde 'flow'-condities samenhangen. Op de thuiswerkplek kunnen werknemers zich naar verwachting beter ontspannen dan 100 op kantoor. Door zich frequenter van collega's en klanten te isoleren, of tijdelijk afstand te nemen van anderen ('disconnect') (Kolb \& Collins, 2009), kunnen ongewenste werkonderbrekingen worden gereduceerd (Bailey \& Kurland, 2002). Idealiter biedt substantieel telewerken dan ook meer tijd, rust en ruimte voor reflectie om informatie te verwerken en zich beter te kunnen concentreren op complexe taken. In het geval van substantieel telewerken zouden werknemers meer in hun werk kunnen opgaan en mogelijk tot creatievere oplossingen kunnen komen. De arbeidstaak zelf wordt daarmee ook interessanter en plezieriger en biedt wellicht meer ruimte voor persoonlijke groei. Op basis van het bovenstaande kan de volgende hypothese met betrekking tot de directe relatie tussen de mate van telewerken en 'flow' worden geformuleerd:

Hypothese ra: Werknemers die substantieel telewerken, ervaren vaker 'flow' dan werknemers die marginaal telewerken.

Wanneer werkkenmerken, zoals (lange) contractuele uren, reistijd, overwerk, en afleiding op kantoor, als stressoren worden ervaren, komen werknemers waarschijnlijk minder vaak tot 'flow'. Wellicht kan door substantieel telewerken het negatieve effect van deze stressoren op 'flow' meer worden tegengegaan dan door marginaal telewerken. In de thuisomgeving kunnen telewerkers immers vaker (ononderbroken) (door) werken (Bailey \& Kurland, 2002), zonder rekening te hoeven houden met opgelegde grenzen, zoals kantoortijden. Hierdoor kunnen vooral substantiële telewerkers zich beter op hun werk concentreren, het arbeidsplezier laten domineren over het gevoel van arbeidsplicht, en gemotiveerder werken. Op basis hiervan kan de volgende "bufferhypothese' met betrekking tot de indirecte relatie tussen de mate van telewerken en 'flow' worden geformuleerd:

Hypothese Ib: De negatieve relatie tussen stressoren (lange contractuele werkuren, reistijd, werkdruk, overwerk, en afleiding op de reguliere werkplek) en 'flow' is minder sterk voor werknemers die substantieel telewerken, dan voor werknemers die marginaal telewerken.

'Flow' wordt vooral ervaren wanneer er hulpbronnen in het werk aanwezig zijn, zoals autonomie in het werk, en steun van de leidinggevende en van collega's (Bakker \& 
Geurts, 2004). Door persoonlijk contact en steun van en samenwerking met anderen kunnen werknemers worden geïnspireerd en gemotiveerd (Kolb \& Collins, 2009). In combinatie met telewerken kan deze positieve relatie wellicht worden versterkt. Telewerkers met een grote mate van autonomie en veel steun vanuit de organisatie ervaren enerzijds waarschijnlijk meer mogelijkheden en vrijheid om zich tijdelijk 'terug te trekken' (Peters \& Van der Lippe, 2007b) ('disconnect'), maar vertrouwen er tevens op dat zij op hun leidinggevende en collega's kunnen terugvallen en hen om hulp kunnen vragen wanneer dat nodig is ('connect') (Kolb \& Collins, 20o9). In combinatie met telewerken vormen hulpbronnen, zoals autonomie en sociale steun, naar verwachting dan ook ideale condities om 'flow' te kunnen ervaren. Op basis hiervan kan de volgende 'versterkingshypothese' worden geformuleerd:

Hypothese Ic: De positieve relatie tussen hulpbronnen (autonomie in het werk en sociale steun van leidinggevende en collega's) en 'flow' is sterker voor werknemers die substantieel telewerken, dan voor werknemers die marginaal telewerken.

\section{Uitputting}

De vermindering van filestress en reistijd en het beter kunnen afstemmen van werkzaamheden op het eigen bioritme worden vaak genoemd als motieven van werknemers om te kiezen voor telewerken (Mokhtarian, Bagley \& Salomon, I998). Werknemers die telewerken hebben geadopteerd geven aan meer tijd en energie over te houden voor activiteiten buiten het werk, zoals slapen en hobby's (Vittersø, Akselsen, Evjemo, Julsrud, Yttri \& Bergvik, 2003; Golden, 2006), en minder vermoeid te zijn (Montreuil \& Lippel, 2003). Het reducerende effect van telewerken op uitputting is waarschijnlijk groter naarmate men vaker telewerkt. Op basis hiervan kan de volgende hypothese ten aanzien van de directe relatie tussen de mate van telewerken en uitputting worden geformuleerd:

Hypothese 2a: Werknemers die substantieel telewerken, ervaren minder uitputting dan werknemers die marginaal telewerken.

Stressoren (zoals lange contractuele uren en reistijden, overwerk, werkdruk, en afleiding op kantoor) gaan vaak samen met meer uitputting onder werknemers (Bakker \& Demerouti, 2007). Zo kunnen werknemers door het werken in een druk kantoor bijvoorbeeld emotionele en mentale energie verspillen, en daardoor meer uitputting ervaren (Golden, 2006). Vooral met het oog op de bovengenoemde genoemde stressoren zou telewerken uitputting kunnen tegengaan. Thuis kunnen werknemers de drukte van het kantoor immers achter zich laten en zich weer opladen, of op een andere manier stressoren beter hanteerbaar maken. Dit zou vooral kunnen gelden voor werknemers die vaker telewerken. Op basis van het bovenstaande kan de volgende bufferhypothese worden geformuleerd:

Hypothese $\mathbf{2 b}$ : De positieve relatie tussen stressoren (lange contractuele werkuren, reistijd, werkdruk, overwerk, en afleiding op de reguliere werkplek) en uitputting is minder sterk voor werknemers die substantieel telewerken, dan voor werknemers die marginaal telewerken. 
Autonomie en steun van leidinggevende en collega's zijn bekende hulpbronnen die het stressniveau van werknemers kunnen reduceren, en daardoor uitputting kunnen tegengaan (Bakker \& Demerouti, 2007). Deze hulpbronnen refereren aan het onderlinge vertrouwen ('trust') tussen de werknemer, de leidinggevende en collega's dat nodig is om succesvol op afstand te kunnen werken (Nilles, 1998). In combinatie met telewerken kan de negatieve samenhang tussen hulpbronnen in het werk en uitputting waarschijnlijk worden versterkt. Werknemers hebben in dat geval niet alleen de beschikking over meer vrijheid in het werk, maar gebruiken deze om vaker thuis rustig te kunnen werken, in de wetenschap dat ze met problemen in het werk bij hun leidinggevende en collega's kunnen aankloppen. Naar verwachting kunnen werknemers die over dergelijke hulpbronnen in het werk beschikken met substantieel telewerken stress en uitputting beter tegengaan dan met marginaal telewerken. Op basis hiervan kan de volgende 'versterkingshypothese' worden geformuleerd:

Hypothese 2c: De negatieve relatie tussen hulpbronnen (autonomie in het werk en sociale steun van leidinggevende en collega's) en uitputting is sterker voor werknemers die substantieel telewerken, dan voor werknemers die marginaal telewerken.

In het voorgaande werd steeds als uitgangspunt genomen dat telewerken kan fungeren als een hulpbron in het werk, die werknemers mogelijkheden biedt om tijdelijk 'afstand' te nemen van anderen, waardoor werknemers tijd hebben voor de reflectie en rust die nodig is om 'flow' te kunnen ervaren én voor het herstel van het werk waarmee uitputting kan worden tegengegaan. Wanneer werknemers op de thuiswerkplek echter worden afgeleid door andere personen of zaken, zullen zij wellicht juist minder in staat zijn om rustig te werken, te reflecteren op het werk, en bij te komen van de arbeidsinspanning. In dat geval zal thuiswerken misschien eerder als stressor dan als hulpbron worden ervaren en zullen substantiële telewerkers waarschijnlijk minder vaak 'flow' ervaren dan marginale telewerkers. In lijn met het voorgaande valt tevens te verwachten dat werknemers, die op de thuiswerkplek veel worden afgeleid, juist meer uitputting ervaren wanneer zij vaker telewerken. Op basis hiervan kan de volgende 'versterkingshypothese' (stressor * stressor) (Van Ruysseveldt et al., 2008) worden geformuleerd:

Hypothese 3: Werknemers die veel afleiding op de thuiswerkplek ervaren, zullen minder 'flow' en meer uitputting ervaren wanneer ze substantieel telewerken, dan wanneer ze marginaal telewerken.

\section{Methode}

\subsection{Onderzoeksdesign en onderzoeksgroep}

In deze studie wordt gebruik gemaakt van een cross-sectionele dataset die werd verzameld onder I.II4 werknemers van dertig organisaties in de publieke en private sector. Hieronder bevonden zich onder andere een energiebedrijf, een verzekeringsbedrijf, een waterbedrijf, een vervoersbedrijf, verschillende onderwijsinstituten en 
gemeenten, een politieorganisatie, een uitzendbureau, een organisatie- \& adviesbureau, een onderzoeksbureau, een bibliotheek, een postbedrijf, en twee zorginstellingen. Werknemers van deze bedrijven werden aan de hand van een uitgebreide computergestuurde werknemersvragenlijst en een schriftelijke vragenlijst ruim één uur tot anderhalf uur bij hen thuis geïnterviewd (Van der Lippe \& Glebbeek, 2004).

In de vragenlijst werd een telewerker gedefinieerd als een werknemer die (voor een gedeelte van de contractuele arbeidstijd) thuis werk verricht in plaats van op kantoor (exclusief overwerk thuis).

Om de zeven hypothesen te toetsen is in de onderhavige studie een selectie gemaakt van werknemers die aangaven 'geregeld' te telewerken $(\mathrm{n}=33 \mathrm{r})$. Respondenten die 'nooit of bijna nooit' telewerkten (70\% van alle respondenten) zijn niet in dit onderzoek meegenomen. Door substantiële telewerkers te vergelijken met marginale telewerkers kunnen eventuele verschillen tussen telewerkers met verschillende telewerkfrequentie worden aangetoond, waarbij tevens wordt voorkomen dat substantiële telewerkers worden vergeleken met werknemers die geen telewerkbare functie hebben.

Van alle respondenten telewerkte 2I.9\% minder dan één dag per week. Deze respondenten vormen de categorie 'marginale telewerkers'. Van alle respondenten telewerkte 5\% één dag per week; I.4\% twee dagen per week; 0.7\% drie dagen per week; $0.4 \%$ vier dagen per week; en $0.3 \%$ vijf dagen per week. Al deze respondenten vormden de categorie 'substantiële telewerkers'. De 'subsample' van telewerkers bestond dan ook voor $73.7 \%(\mathrm{n}=244)$ uit werknemers, die wel geregeld, maar gemiddeld minder dan één dag per week telewerken ('marginale telewerkers'), en voor $26.3 \%(n=87)$ uit werknemers die gemiddeld één dag per week of vaker telewerken ('substantiële telewerkers').

Van de respondenten in de onderhavige studie is $59 \%$ man en $4 \mathrm{I} \%$ vrouw. De gemiddelde leeftijd is 40.6 jaar $(\mathrm{SD}=8.6$ ). De jongste respondent is 24 , de oudste is 63 jaar oud. Hoogopgeleiden (hbo, wo, of gepromoveerd) zijn sterk oververtegenwoordigd (84\%). De meesten ( $78 \%$ zijn al dan niet gehuwd samenwonend, $22 \%$ is alleenstaand. Meer dan de helft van de respondenten (54\%) heeft een thuiswonend kind. Van $46 \%$ is het kind jonger dan dertien jaar. Als gevolg van de selectie was geen van de werknemers in de twee zorginstellingen in deze studie betrokken.

\subsection{Meetinstrumenten}

\section{Werkkenmerken}

De mate van telewerken werd gemeten door een dichotome variabele. De score ( $\mathrm{I}$ ) representeert 'substantieel telewerken'. 'Marginaal telewerken' vormt de referentiecategorie (o).

Contractuele arbeidsuren werden gemeten door de respondent te vragen naar het gemiddelde aantal contractuele arbeidsuren per week.

Reistijd werd gemeten door te vragen naar de tijd die men gemiddeld kwijt is met het reizen naar de reguliere werkplek (kantoor) ('Hoeveel reistijd bent u gemiddeld kwijt om naar uw werk te gaan?' Het antwoord werd gegeven in minuten.

Werkdruk werd gemeten door drie items uit de 'Vragenlijst Beleving en Beoordeling van de Arbeid'(VBBA) (Van Veldhoven \& Meijman, 1994). De items refereren aan 
werktempo en werkhoeveelheid ( $\mathrm{I}=$ altijd; 5 = nooit). Bijvoorbeeld: 'Heeft u te veel werk te doen?' De scores werden gehercodeerd, zodat een hogere score correspondeert met een hogere werkdruk (Cronbachs alpha $=.67$ ).

Overwerkfrequentie werd gemeten door een enkele vraag: 'Hoe vaak komt het voor dat $\mathrm{u}$ 's avonds of in het weekend moet overwerken?' ( $\mathrm{r}=$ altijd; $5=$ nooit). De scores werden gehercodeerd, zodat een hogere score correspondeert met frequenter overwerk.

Afleiding op de reguliere werkplek (het kantoor) werd gemeten door drie zelf geconstrueerde items ( $\mathrm{I}=$ altijd; 5 = nooit). Deze items waren: $\mathrm{I}) \mathrm{Ik}$ ondervind geluidshinder van (lopende en pratende) collega's; 2) Ik word tijdens mijn werk afgeleid door mijn collega's; 3) Ik word tijdens mijn werk afgeleid door geluiden van apparaten (telefoons, fax, computers, et cetera). De scores werden gehercodeerd, zodat een hogere score correspondeert met meer afleiding op de reguliere werkplek (Cronbachs

Afleiding op de thuiswerkplek werd gemeten door drie zelf geconstrueerde items ( $\mathrm{I}$ = altijd; 5 = nooit), gebaseerd op de items die 'afleiding op de reguliere werkplek' meten. Deze items waren: I) Ik ondervind geluidshinder van anderen (buren of huisgenoten); 2) Ik word tijdens mijn werk thuis afgeleid door anderen; 3) Ik word tijdens mijn werk thuis afgeleid door geluiden van apparaten. De scores werden gehercodeerd, zodat een hogere score correspondeert met meer afleiding op de thuiswerkplek (Cronbachs alpha $=.68)$.

Autonomie in het werk werd gemeten door drie items ( $1=$ altijd; $5=$ nooit $)$, zoals gebruikt door Bakker, Demerouti en Verbeke (2004) die hun items baseerden op de schaal van Karasek (1985). Bijvoorbeeld: 'Heeft u vrijheid bij het uitvoeren van uw werkzaamheden?' De scores op deze vragen werden gehercodeerd, zodat een hogere score correspondeert met meer autonomie (Cronbachs alpha =.69).

Sociale steun van de leidinggevende werd gemeten door vijf items ( $\mathrm{I}=$ helemaal mee eens; 5 = helemaal mee oneens). Bijvoorbeeld: 'Mijn leidinggevende gebruikt zijn/ haar invloed om mij te helpen problemen op te lossen' (Scheeres \& Bakker, 2003). De scores werden gehercodeerd, zodat een hogere score correspondeert met meer ervaren steun van de leidinggevende (Cronbachs alpha $=.89$ ).

Sociale steun van collega's werd gemeten door drie items ( $\mathrm{I}=$ altijd; 5 = nooit). Bijvoorbeeld: 'Kunt u als dat nodig is uw collega's om hulp vragen?' (Bakker et al., 2004). De scores werden gehercodeerd, zodat een hogere score correspondeert met meer sociale steun van collega's (Cronbachs alpha $=.80$ ).

\section{Werkuitkomsten}

De frequentie waarmee telewerkers de maand voorafgaand aan het onderzoek 'flow' hadden ervaren, werd gemeten met behulp van de 'WOrk-reLated Flow inventory' (WOLF) (Bakker, 2008). Dit instrument meet de drie 'flow'-dimensies met behulp van dertien uitspraken ( $\mathrm{I}=$ altijd; 7 = nooit). Intrinsieke motivatie werd gemeten door vijf items. Bijvoorbeeld: 'Ik doe mijn werk zonder me af te vragen wat het mij oplevert.' Arbeidsplezier werd gemeten door vier items. Bijvoorbeeld: 'Mijn werk geeft me een goed gevoel.' Ook absorptie werd gemeten door vier items. Bijvoorbeeld: 'Als 
ik met mijn werk bezig ben, denk ik aan helemaal niets anders.' De itemscores werden gehercodeerd, zodat een hogere score correspondeert met een hogere 'flow'-frequentie. De Cronbachs alpha van de totale 'flow'-schaal op basis van de dertien 'flow'-items bedroeg .89.

De frequentie waarmee de respondent het jaar voorafgaand aan het onderzoek uitputting had ervaren, werd gemeten door drie items ( $\mathrm{I}=$ elke dag; $7=$ nooit $)$ gebaseerd op de Utrechtse 'Burnout'-schaal (UBOS), die de antwoordcategorieën van o tot 6 hanteert (Schaufeli \& Van Dierendonck, 20or). Bijvoorbeeld: 'Ik voel me mentaal uitgeput door mijn werk.' De scores werden gehercodeerd, zodat een hogere score correspondeert met een hogere uitputtingsfrequentie (Cronbachs alpha $=.85$ ).

\subsection{Data-analyse}

Om hypothesen ia en $2 \mathrm{a}$ te toetsen en om inzicht te krijgen in de werkkenmerken van de twee onderscheiden telewerkcategorieën werd allereerst een Manova-analyse uitgevoerd (tabel 2). Daarna werden meervoudige regressieanalyses uitgevoerd met 'flow' en uitputting als afhankelijke variabelen. Om de verwachte interacties tussen de mate van telewerken en de werkkenmerken (stressoren en hulpbronnen) te toetsen (hypothesen Ib, Ic, 2b, 2c en 3) zijn eerst de hoofdeffecten en daarna negen producttermen (STW x werkkenmerken) in een regressiemodel gevoegd (zie tabel 3 , modellen I en 2) (Baron \& Kenny, 1986). Hiervoor zijn de scores op de onafhankelijke variabelen, met uitzondering van de telewerkdummy, gecentreerd (Field, 2009).

Voor het visualiseren van de significante interacties tussen werkkenmerken en substantieel telewerken in de voorspelling van de uitkomstvariabelen werden de ongestandaardiseerde regressiecoëfficiënten gebruikt (figuren I, 2 en 3). Om het gewicht van de variabelen in de verklaring van 'flow' en uitputting te kunnen weergeven, werden in tabel 3 de gestandaardiseerde regressiecoëfficiënten (bèta's) gerapporteerd. Aangezien de modellen relatief veel onafhankelijke variabelen bevatten in vergelijking met het antal cases, wordt de Adjusted $R^{2}$ in tabel 3 vermeld.

\section{Resultaten}

In tabel I wordt de correlatieanalyse gepresenteerd van de variabelen die in de multivariate analyses zijn opgenomen. 'Flow' en uitputting blijken significant negatief met elkaar te correleren $(r=-.33)$. Correlatieanalyse laat zien dat er geen sprake is van multicollineariteit tussen de werkkenmerken. De hoogste correlatie wordt gevonden tussen de variabelen 'steun van de leidinggevende' en 'steun van collegas' $(r=.35)$. Deze is niet hoger dan de grenswaarde van .80 of .90. (Field, 2009).

In tabel 2 worden de uitkomsten van de Manova-analyse gepresenteerd. Deze laten zien dat de twee telewerkcategorieën met betrekking tot de scores op de afhankelijke en onafhankelijke variabelen significant van elkaar verschillen $F(\mathrm{II}, 303)=4.26$, $p<$. oor. Univariate toetsing laat zien dat substantieel telewerken in vergelijking met marginaal telewerken samengaat met significant meer 'flow' $F(\mathrm{I}, 3 \mathrm{I} 3)=5.20, p<.05$; meer reistijd $F(\mathrm{I}, 3 \mathrm{I} 3)=\mathrm{II} .72, p<.00 \mathrm{I}$; significant minder werkdruk $F(\mathrm{I}, 3 \mathrm{I} 3)=3.78$, $p<$. Io; significant minder afleiding op de reguliere werkplek $F(\mathrm{I}, 3 \mathrm{I} 3)=3.30, p<$. IO; 


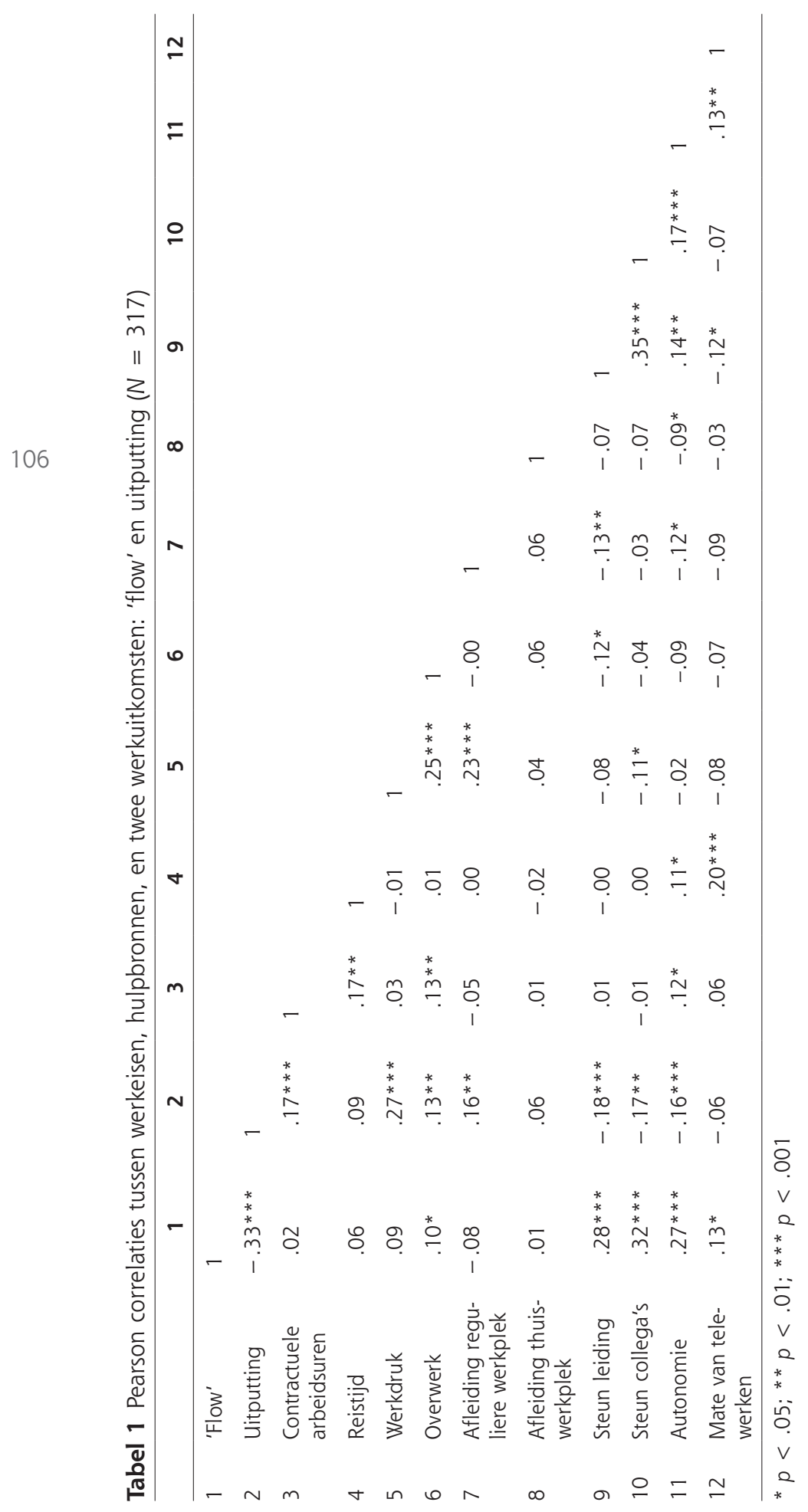


significant minder ervaren steun van de leidinggevende $F(\mathrm{I}, 3 \mathrm{I} 3)=5.33, p<.05$; significant minder ervaren steun van collega's $F(\mathrm{I}, 3 \mathrm{I} 3)=2.98, p<$. IO ; en significant meer ervaren autonomie in het werk $F(\mathrm{r}, 3 \mathrm{I} 3)=4.35, p<.05$. De gemiddelden van de overige variabelen verschillen niet significant tussen de twee telewerkcategorieën. De Manova-analyse toont dan ook aan dat substantieel telewerken gemiddeld genomen wel gepaard gaat met meer 'flow' (hypothese ra bevestigd), maar niet met minder uitputting (hypothese 2 a verworpen).

Tabel 2 Vergelijking van gemiddelde scores tussen marginaal ( $<1$ dag p/w) en substantieel ( $\geq 1$ dag $\mathrm{p} / \mathrm{w}$ ) telewerken

\begin{tabular}{lccc}
\hline & \multicolumn{3}{c}{ Means } \\
\hline & $\begin{array}{c}\text { Marginaal } \\
\text { Telewerken } \\
(\mathbf{n}=\mathbf{2 4 4})\end{array}$ & $\begin{array}{c}\text { Substantieel } \\
\text { Telewerken } \\
(\mathbf{n}=\mathbf{8 7})\end{array}$ & $\begin{array}{c}\text { Significantie } \\
\text { Verschil in } \\
\text { gemiddelden }\end{array}$ \\
\hline 'Flow' & 4.51 & 4.74 & $* *$ \\
Uitputting & 3.50 & 3.33 & \\
Contractuele arbeidsuren & 34.38 & 34.94 & $*$ * \\
Reistijd naar werk & 38.81 & 51.29 & $\#$ \\
Werkdruk & 3.34 & 3.15 & $\#$ \\
Overwerkfrequentie & 2.02 & 1.82 & $*$ \\
Afleiding op de reguliere werkplek & 2.19 & 1.98 & $*$ \\
Afleiding op de thuiswerkplek & 1.43 & 1.37 & $*$ \\
Steun van leidinggevende & 3.71 & 3.49 & $*$ \\
Steun van collega's & 3.84 & 3.66 & $*$ \\
Autonomie in het werk & 4.08 & 4.26 & $*$ \\
\hline
\end{tabular}

$\# p<.10 ;{ }^{*} p<.05 ; * *<.01 ; * * p<.001$

In tabel 3 worden de resultaten van de meervoudige regressieanalyse voor 'flow' gepresenteerd, zonder (model I) en met interactie-termen (model 2). In het onderstaande wordt model 2 besproken.

In lijn met hypothese ra zien we dat substantieel telewerken in vergelijking met marginaal telewerken samengaat met significant meer 'flow' in het werk (bèta $\left.=.19^{* * *}\right)$. In tegenstelling tot hypothesen $\mathrm{Ib}$ en Ic zijn de interacties tussen de overige werkkenmerken en substantieel telewerken niet significant. In tegenstelling tot de verwachting zoals geformuleerd in hypothese 3 blijken werknemers die veel afleiding op de thuiswerkplek rapporteren juist vaker 'flow' te ervaren wanneer ze substantieel telewerken, dan wanneer ze marginaal telewerken $\left(\right.$ bèta $\left.=. I 4^{* *}\right)$. Figuur I laat zien dat substantiële telewerkers over de hele linie meer 'flow' beleven dan marginale telewerkers, maar dat het verschil in 'flow'-frequentie tussen de twee telewerkcategorieën groter is wanneer telewerkers meer afleiding op de thuiswerkplek ervaren. 
Tabel 3 Meervoudige regressieanalyses ( $N=314$; gestandaardiseerde regressiecoëfficiënten (bèta))

\begin{tabular}{|c|c|c|c|c|c|}
\hline \multirow{2}{*}{\multicolumn{2}{|c|}{ Variabelen }} & \multicolumn{2}{|c|}{ 'Flow' } & \multicolumn{2}{|c|}{ Uitputting } \\
\hline & & \multirow{2}{*}{$\begin{array}{l}\text { Model } 1 \\
-.04\end{array}$} & \multirow{2}{*}{$\begin{array}{l}\text { Model } 2 \\
-.02\end{array}$} & \multirow{2}{*}{$\begin{array}{r}\text { Model } 1 \\
.17^{* * *}\end{array}$} & \multirow{2}{*}{$\begin{array}{c}\text { Model } 2 \\
.15^{* *}\end{array}$} \\
\hline 1. & Contractuele werkuren & & & & \\
\hline 2. & Reistijd & .02 & .01 & .09 & .07 \\
\hline 3. & Werkdruk & $.13^{*}$ & .12 & $.22 * * *$ & $.23 * * *$ \\
\hline 4. & Overwerk & $.14^{* *}$ & $.12^{*}$ & .02 & .07 \\
\hline 5. & $\begin{array}{l}\text { Afleiding op de reguliere } \\
\text { werkplek }\end{array}$ & -.04 & -.02 & .08 & .07 \\
\hline 6. & Afleiding op de thuiswerkplek & .06 & .00 & .03 & .03 \\
\hline 7. & Steun van leidinggevende & $.20 * * *$ & $.22 * * *$ & $-.10^{*}$ & -.12 \\
\hline 8. & Steun van collega's & $.25 * * *$ & $.24 * * *$ & -.07 & -.07 \\
\hline 9. & Autonomie in het werk & $.21^{* * *}$ & $.21 * * *$ & $-.15^{* *}$ & -.09 \\
\hline 10. & $\begin{array}{l}\text { Substantieel telewerken } \\
{[\text { ref. = marginaal }]} \\
{[0=\text { af-en-toe; } 1=\text { frequent }]}\end{array}$ & $.18^{* * *}$ & $.19 * * *$ & -.04 & -.04 \\
\hline \multicolumn{2}{|c|}{ STW $\times$ Contractuele uren } & & -.04 & & .04 \\
\hline \multicolumn{2}{|c|}{ STW $\times$ Reistijd } & & .01 & & .05 \\
\hline \multicolumn{2}{|c|}{ STW x Werkdruk } & & .01 & & -.01 \\
\hline \multicolumn{2}{|c|}{ STW x Overwerk } & & .05 & & $-.12^{*}$ \\
\hline \multicolumn{2}{|c|}{$\begin{array}{l}\text { STW } x \text { Afleiding op de reguliere } \\
\text { werkplek }\end{array}$} & & -.02 & & .011 \\
\hline \multicolumn{2}{|c|}{ STW $x$ Afleiding op de thuiswerkplek } & & $.14^{* *}$ & & -.02 \\
\hline \multicolumn{2}{|c|}{ STW $\times$ Steun leidinggevende } & & -.03 & & .025 \\
\hline \multicolumn{2}{|c|}{ STW $\times$ Steun collega's } & & .06 & & -.014 \\
\hline \multicolumn{2}{|c|}{ STW $\times$ Autonomie } & & .03 & & $-.11 *$ \\
\hline \multicolumn{2}{|c|}{$\mathrm{F}$} & $9.71 * * *$ & $5.46 * * *$ & $6.11 * * *$ & $3.57 * * *$ \\
\hline \multicolumn{2}{|c|}{ Adjusted $R^{2}$ in \% } & 21.7 & 21.2 & 13.9 & 13.4 \\
\hline
\end{tabular}

${ }^{*} p<.05 ;{ }^{*} p<.01 ; * * *<.001 ;$ hypothesen éénzijdig getoetst

In tabel 3 worden ook de resultaten van de meervoudige regressieanalyse voor uitputting gepresenteerd. De uitkomsten van het regressiemodel met interactietermen wordt hieronder besproken ( tabel $_{3}$, uitputting model 2). In tegenstelling tot hypothese 2 a blijkt substantieel telewerken in vergelijking met marginaal telewerken niet samen te gaan met minder uitputting (bèta $=-.04$ ). Hypothesen $2 \mathrm{~b}$ en $2 \mathrm{c}$ worden echter wel gedeeltelijk door de data ondersteund. Twee interactietermen blijken een significante samenhang te vertonen met uitputting: substantieel telewerken $\mathrm{x}$ overwerk (bèta $=-.12^{*}$ ) en substantieel telewerken $\mathrm{x}$ autonomie (bèta $=-$. II $^{*}$ ). 


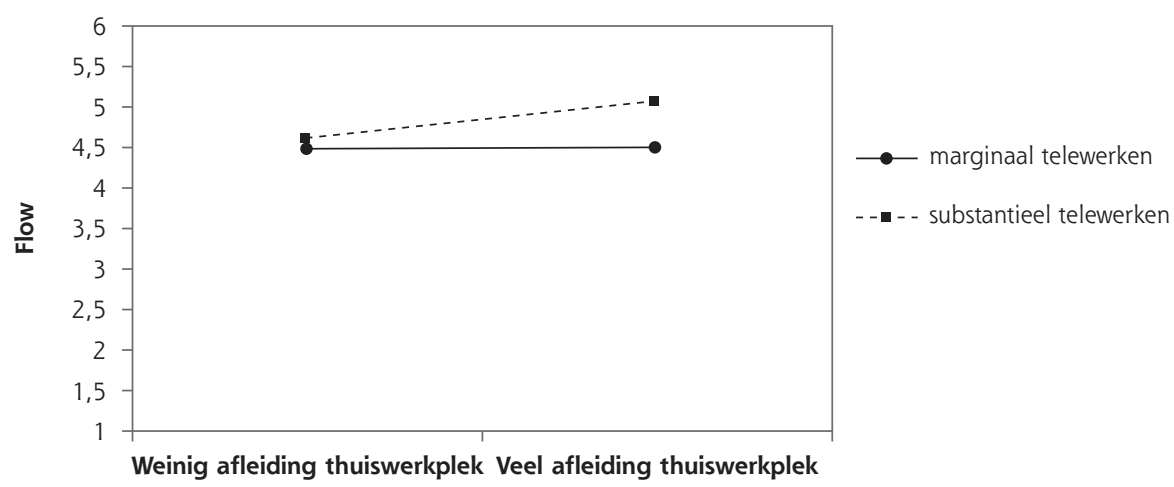

Figuur 1 De interactie tussen afleiding op de thuiswerkplek en de mate van

telewerken in de voorspelling van 'flow' in het werk

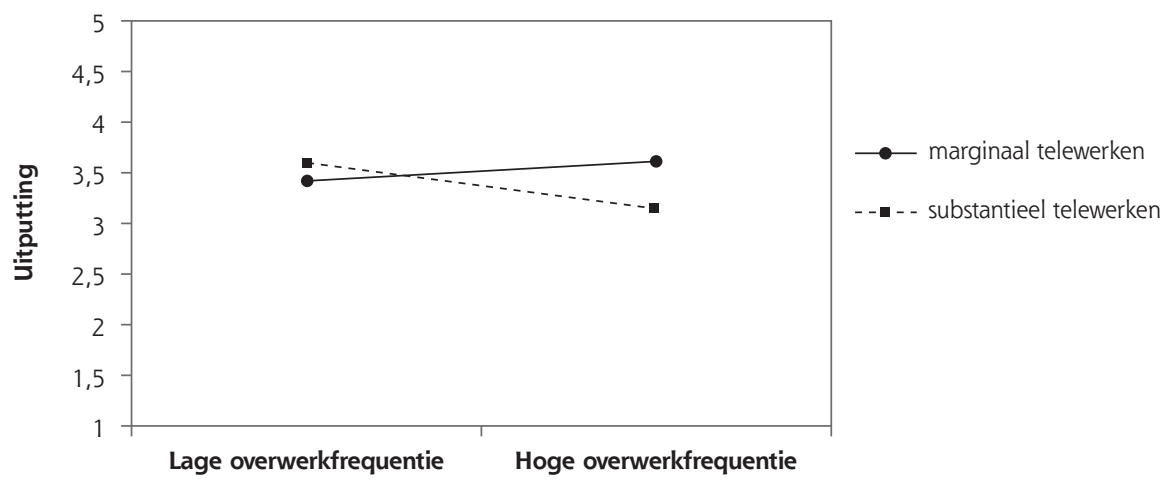

Figuur 2 De interactie tussen overwerkfrequentie en de mate van telewerken in de voorspelling van uitputting in het werk

Figuur 2 laat zien dat werknemers bij een lage overwerkfrequentie meer uitputting ervaren wanneer zij substantieel telewerken, dan wanneer zij marginaal telewerken. Wanneer werknemers echter frequent overwerken, is hun uitputtingsniveau juist lager wanneer zij substantieel telewerken, dan wanneer zij marginaal telewerken. Dit laatste is in lijn met hypothese $2 \mathrm{~b}$ waarin wordt gesteld dat substantieel telewerken het positieve effect van overwerk op uitputting kan bufferen.

Figuur 3 laat zien dat werknemers met weinig autonomie meer uitputting ervaren wanneer ze substantieel thuiswerken. Echter, wanneer werknemers meer autonomie hebben, ervaren ze juist minder uitputting wanneer ze substantieel telewerken, dan wanneer ze marginaal telewerken. Zoals voorspeld in hypothese $2 \mathrm{c}$ blijkt substantieel telewerken het reducerende effect van een hoge mate van autonomie op uitputting te versterken. In tegenstelling tot hypothesen $2 \mathrm{a}$ en $2 \mathrm{~b}$ blijken de overige interactietermen niet significant te zijn. 


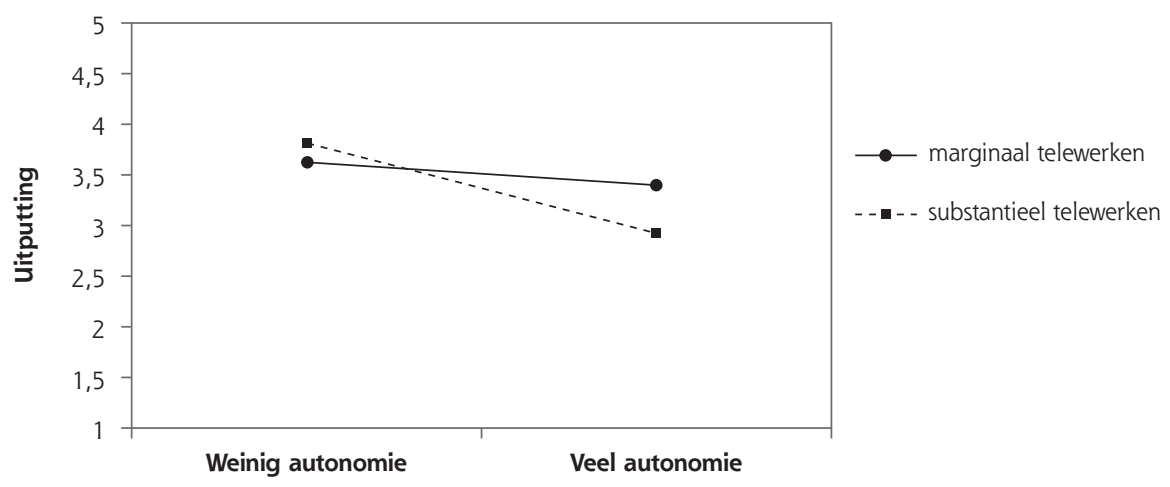

110 Figuur 3 De interactie tussen autonomie in het werk en de mate van telewerken in de voorspelling van uitputting in het werk

Volgens hypothese 3 zullen werknemers, die veel afleiding op de thuiswerkplek rapporteren meer uitputting ervaren wanneer zij substantieel telewerken, dan wanneer zij marginaal telewerken. De resultaten van de regressieanalyse tonen echter niet aan dat meer afleiding op de thuiswerkplek in combinatie met substantieel thuiswerken samengaat met meer uitputting.

\section{Discussie en conclusie}

Voorstanders van telewerken zien (thuis)werken op afstand (van het reguliere kantoor) met behulp van ICT als een hulpbron in het werk, die werknemers onder andere de benodigde ruimte biedt voor reflectie op en herstel van het werk, en daarom naar verwachting zal samengaan met positieve werkuitkomsten. Wanneer een werknemer op de thuiswerkplek veel wordt afgeleid, zou telewerken wellicht juist als stressor kunnen worden ervaren. De onderhavige studie sluit dan ook aan bij het maatschappelijke en wetenschappelijke debat over het belang van de telewerkfrequentie voor het behalen van positieve werkuitkomsten (Bailey \& Kurland, 2002) door specifiek in te gaan op de vraag of werknemers die één dag of meer per week, ofwel 'substantieel' telewerken vaker 'flow' en minder uitputting ervaren dan werknemers die minder dan één dag per week, ofwel 'marginaal' telewerken. Daarnaast werd de bufferende en versterkende rol die substantieel telewerken bij de aanwezigheid van bepaalde stressoren en hulpbronnen in het werk kan spelen, nader onderzocht. Om de verwachtingen rondom de directe en indirecte relaties tussen de mate van telewerken enerzijds en 'flow' en uitputting anderzijds te toetsen, werden in dit onderzoek alleen werknemers geselecteerd die regelmatig, maar in verschillende mate telewerkten. De resultaten van deze studie worden hieronder samengevat en bediscussieerd. 


\subsection{Theoretische implicaties}

Flow

De onderhavige studie liet zien dat substantiële telewerkers over de hele linie vaker 'flow' ervoeren dan marginale telewerkers, ook wanneer werd gecontroleerd voor andere werkkenmerken die met 'flow' samenhangen. Substantieel telewerken kan wat betreft het ervaren van 'flow' van de werknemers in deze studie dan ook met recht een hulpbron in het werk worden genoemd. De theoretische verklaring voor de directe, positieve samenhang tussen substantieel telewerken en 'flow' werd gezocht in de veronderstelling dat werknemers voor het verkrijgen van 'flow' niet alleen geïnspireerd en gemotiveerd kunnen worden door persoonlijk contact en steun van anderen, maar juist ook door de mogelijkheid om zich veelal vrijwillig en tijdelijk van anderen af te sluiten door op afstand te werken (Kolb \& Collins, 20o9). Juist door vaker (fysieke) afstand van collega's en klanten te nemen, kunnen ongewenste werkonderbrekingen worden gereduceerd, waardoor substantiële telewerkers in vergelijking met marginale telewerkers meer tijd, rust en ruimte voor reflectie krijgen die bijvoorbeeld nodig is om informatie te verwerken, en zich te kunnen concentreren op complexe taken. De substantiële telewerkers in deze studie bleken inderdaad meer dan marginale telewerkers die onder vergelijkbare werkomstandigheden hun werkzaamheden uitvoeren, in staat te zijn om in hun werk op te gaan, werkplezier te hebben, of de intrinsieke werkmotivatie te laten prevaleren.

Opmerkelijk is echter dat er geen ondersteuning werd gevonden voor de veronderstelling dat substantieel telewerken, in vergelijking met marginaal telewerken, vooral onder bepaalde werkcondities tot meer 'flow' leidt. In tegenstelling tot de verwachtingen bleek substantieel telewerken het demotiverende effect van stressoren (in casu contractuele arbeidsuren, reistijd, werkdruk, overwerk, en afleiding op de reguliere werkplek) op 'flow' niet meer te bufferen dan marginaal telewerken. In tegenstelling tot de verwachtingen bleek substantieel telewerken ook niet samen te gaan met een positievere relatie tussen andere hulpbronnen (sociale steun en autonomie) en 'flow'.

In strijd met de verwachtingen bleken werknemers die meer afleiding op de thuiswerkplek rapporteerden juist vaker 'flow' te beleven wanneer zij substantieel telewerkten dan wanneer ze marginaal telewerkten. Opgemerkt moet worden dat beide categorieën telewerkers relatief weinig afleiding rapporteerden op de thuiswerkplek. De uitkomst van dit onderzoek toont wellicht aan dat substantiële telewerkers juist baat hebben bij enige afleiding op de thuiswerkplek en sociaal contact met anderen op hun thuiswerkdagen. Juist de combinatie tussen afleiding (op de thuiswerkplek) en 'afstand nemen' zou kunnen voorkomen dat telewerkers in een sociaal isolement geraken (Kurland \& Cooper, 2002). Deze verklaring lijkt in eerste instantie strijdig met het theoretische uitgangspunt van deze studie, maar vormt wellicht een nuancering van het idee dat telewerkers behoefte hebben aan of gebaat zijn bij volledige afzondering. Vervolgonderzoek zou kunnen ingaan op de rol die afleiding en sociaal contact speelt bij het genereren van 'flow' onder telewerkers. Welke mechanismen precies werkzaam zijn, kon met deze studie niet worden onderzocht. Nader onderzoek zou zich kunnen richten op hulpbronnen in de thuiswerksituatie, zoals hulp en steun in het werk van collega's of van de partner van de werknemer thuis, of op werk- en combinatiestrategieën die telewerkers hanteren om enerzijds afstand van collega's en 
klanten te kunnen nemen, maar anderzijds ook met hen in contact te kunnen blijven wanneer men op afstand werkt. Een alternatieve verklaring voor de positieve interactie tussen substantieel telewerken en afleiding op de thuiswerkplek ten aanzien van 'flow' kan zijn dat er sprake is van een 'selectie-effect'. Het is mogelijk dat vooral telewerkers die meer 'flow' ervaren, werkonderbrekingen (door geluid van apparaten, huisgenoten, buren of anderen) eerder als afleiding bestempelen dan telewerkers die minder 'flow' ervaren. Of deze alternatieve verklaring hout snijdt zal verder moeten worden onderzocht.

\section{Uitputting}

De verwachting dat substantieel telewerken onder alle condities als een hulpbron in het werk kan worden beschouwd, die werknemers meer mogelijkheden biedt om zich te herstellen van en zich weer op te laden voor het werk dan marginaal telewerken,

112 werd in dit onderzoek niet gesteund. Alleen onder sommige condities bleek substantieel telewerken uitputting beter te kunnen pareren dan marginaal telewerken. Zo bleken vooral werknemers die frequent overwerkten minder uitputting te ervaren wanneer zij substantieel thuis werkten. Met andere woorden, frequent overwerken bleek minder belastend te zijn wanneer werknemers relatief vaker thuis werkten. Het is aannemelijk te veronderstellen dat werknemers die frequent moeten overwerken, minder vermoeid raken wanneer zij het (over)werk thuis in een meer ontspannen tempo kunnen uitvoeren, of op door hen zelf te bepalen tijden. Omgekeerd is het ook voorstelbaar dat werknemers die vaker telewerken geneigd zijn om frequenter over te werken, juist omdat zij minder door kantoortijden worden belemmerd. Opmerkelijk is dat werknemers die aangaven niet frequent over te werken juist meer uitputting ervoeren wanneer zij substantieel telewerkten. Misschien missen deze substantiële telewerkers de sociale contacten met collega's die hen inspireren en energie geven, terwijl zij niet de vrijheid of mogelijkheid hebben om het werk in een meer ontspannen tempo uit te voeren en meer tijd voor hun werk te kunnen nemen. Substantieel telewerken is in dat geval wellicht eerder een stressor dan een hulpbron. De interactie tussen de mate van telewerken, autonomie en overwerk in relatie tot uitputting vraagt om nader onderzoek.

In lijn met de verwachtingen liet het onderzoek zien dat een hoge mate van autonomie vooral bij substantieel telewerken met minder uitputting samengaat. Opvallend genoeg bleek dat werknemers die weinig autonomie in het werk ervoeren juist meer uitputting rapporteerden wanneer zij substantieel telewerkten, dan wanneer zij marginaal telewerkten. Ook wanneer telewerkers minder autonomie in het werk hebben, lijkt substantieel telewerken dan ook geen hulpbron, maar veeleer een stressor te zijn.

\subsection{Aanbevelingen voor de praktijk}

Bovenstaande bevindingen laten zien dat substantieel telewerken onder sommige arbeidscondities kansen biedt voor organisaties om de werkuitkomsten van werknemers te verbeteren die met marginaal telewerken in mindere mate kunnen worden behaald. In vergelijking met marginaal telewerken lijkt substantieel telewerken direct te kunnen bijdragen aan meer 'flow' in het werk. Daarnaast suggereren de resultaten dat substantieel telewerken onder sommige condities als hulpbron kan worden ingezet om vermoeidheid onder werknemers tegen te gaan. In deze studie bleek substan- 
tieel telewerken een hulpbron te kunnen zijn die uitputting kan tegengaan onder werknemers die vaker (moeten of kunnen) overwerken en onder werknemers die een hoge mate van autonomie in het werk ervaren. Voor werknemers die niet vaak overwerken en die relatief weinig autonomie in het werk hebben, blijkt substantieel telewerken echter veeleer een stressor te zijn die met meer vermoeidheid in het werk gepaard gaat.

Het optreden van interactie-effecten is echter vaak contextafhankelijk (Van Ruysseveldt, Taverniers, \& Smulders, 2009). Dit impliceert dat de uitkomsten van deze studie niet direct te vertalen zijn naar alle organisatiecontexten en werknemerscategorieën. Het onderhavige onderzoek had immers betrekking op een specifieke selectie werknemers, die konden telewerken en dat ook regelmatig deden, weliswaar in verschillende mate. De telewerkers in deze studie bleken veelal hoogopgeleid met veel autonomie in het werk. Juist autonomie blijkt een belangrijke conditie te zijn voor het verkrijgen van 'flow' en het reduceren van uitputting (Bakker \& Geurts, 2004; Salanova, Bakker \& Llorens, 2006; Scheeres \& Bakker, 2003). Bovendien blijft kritisch (voor)onderzoek vereist, naar het draagvlak voor telewerken, de beste combinatie van condities waaronder substantieel telewerken wordt ingevoerd, en de mogelijke gevolgen van de invoering van telewerken voor de organisatie, individuele werknemers, en andere belanghebbenden in een bepaalde organisatiecontext (Peters, Bleijenbergh \& Oldenkamp, 2009).

Een ander punt dat in deze studie naar voren kwam, was het belang van sociaal contact. Juist het gebrek aan sociaal contact met de leidinggevende en collega's is één van de meest gevreesde nadelen van telewerken (Beffers \& Van den Brink, 2008; Gajendran \& Harrison, 2007; Walrave, 2005), en daarom reden voor managers om marginaal telewerken boven substantieel telewerken te prefereren (Peters et al., 2010). Eerdere studies toonden aan dat het gevoel van isolement door (substantieel) telewerken inderdaad kan worden versterkt (Mann \& Holdsworth, 2003; Montreuil \& Lippel, 2003). In lijn hiermee bleek uit de onderhavige studie dat substantiële telewerkers gemiddeld genomen minder sociale steun ondervonden dan marginale telewerkers. Het belang van het bewaken van kwalitatief goede interne arbeidsrelaties in telewerksituaties, waarin telewerkers, collega's en leidinggevenden wederzijds op elkaar kunnen vertrouwen (Nilles, 1998) voor het verkrijgen van positieve werkuitkomsten, wordt met de onderhavige studie nog eens onderstreept.

\subsection{Vervolgonderzoek}

Tot op heden is telewerken veelal een marginale organisatiepraktijk die vooral toegankelijk is voor hoger opgeleide werknemers met veel autonomie in het werk en die op output worden beoordeeld (Peters \& Van der Lippe, 2007b). Gezien de huidige aandacht voor 'Het Nieuwe Werken', waarvan telewerken vaak een essentieel onderdeel uitmaakt, valt echter te verwachten dat het aantal substantiële telewerkers zal toenemen. Vervolgonderzoek zou zich kunnen richten op werkzaamheden die op dit moment minder voor de hand liggen om 'op afstand uit te voeren', zoals de werkzaamheden van lager opgeleiden met minder autonomie in het werk. Op basis van de uitkomsten van dit onderzoek is het de vraag of substantieel telewerken ook voor deze werknemerscategorieën 'flow' genereert. In vervolgonderzoek kan bovendien worden ingegaan op de rol die de typen werkzaamheden, de mogelijke coördinatie- 
problemen bij samenwerking, en de basiswaarden van werknemers en managers spelen bij de beleving van 'flow' en uitputting onder telewerkers.

In deze studie werd er bovendien impliciet van uitgegaan dat telewerken vrijwillig plaatsvindt. Met de invoering van zogenaamde flexkantoren is deze keuzevrijheid niet altijd meer vanzelfsprekend. De vraag is of substantieel telewerken ook gepaard gaat met meer 'flow' en onder sommige condities met minder uitputting, wanneer werknemers min of meer verplicht worden om thuis te werken. Op dit moment is telewerken bovendien nog vaak beperkt tot één of twee dagen per week (Peters \& Batenburg, 2004). Toekomstig onderzoek zou kunnen nagaan welke balans tussen onderlinge betrokkenheid, autonomie, en distantie (aantal telewerkdagen) optimaal is voor het behalen van positieve werkuitkomsten.

Tot slot, in het telewerkdebat wordt telewerken vaak gezien als een 'win-win-situatie'. Wanneer telewerkers meer plezier in hun werk hebben, zich beter kunnen concen-

114 treren, en gemotiveerder zijn, én wanneer zij zich fit voelen, zullen zij naar verwachting meer tevreden over hun arbeidsleven zijn. Dit kan zowel ten goede komen aan de prestaties van individuele werknemers, als aan die van de organisatie als geheel (Demerouti, Taris \& Bakker, 2007; Boxall \& Purcell, 2003; Petty, McGee \& Cavender, I984; Isen, 2000; Wright \& Cropanzano, 1998). In dit onderzoek werden de relaties tussen substantieel telewerken, positieve werkuitkomsten en individuele en organisatieperformance echter niet onderzocht. Om deze relaties goed te kunnen bestuderen is longitudinaal onderzoek gewenst, onder andere om na te gaan hoe telewerken, 'flow' en uitputting elkaar op langere termijn wederzijds beïnvloeden, en daarmee de performance van de organisatie mogelijk duurzaam versterken.

\section{Praktijkbox:}

- Organisaties laten mogelijk kansen liggen door marginaal telewerken (minder dan één dag in de week) te prefereren boven substantieel telewerken (één dag per week of meer).

- Substantieel telewerken heeft voor de in deze studie onderzochte telewerkers meer potentie om 'flow' (arbeidsplezier, intrinsieke motivatie en concentratie) tijdens het werk te genereren dan marginaal telewerken.

- Wanneer afleiding op de thuiswerkplek samengaat met substantieel thuiswerken, ervaren telewerkers meer 'flow', maar niet meer uitputting. Dit wijst op het belang van het voorkomen van professionele en sociale isolatie bij thuiswerken.

- Wanneer telewerkers vaker overwerken, ervaren zij minder uitputting wanneer zij één dag of meer per week thuiswerken.

- Wanneer telewerkers meer autonomie in het werk hebben, ervaren ze minder uitputting wanneer zij één dag per week of meer thuiswerken.

- Voorgaande uitkomsten hebben betrekking op een relatief hoogopgeleide werknemerspopulatie. Meer onderzoek is nodig naar de effecten van substantieel telewerken voor positieve werkuitkomsten onder andere groepen werknemers. 


\section{Literatuur}

Bailey, D.E. \& Kurland, N.B. (2002). A review of telework research: findings, new directions, and lessons for the study of modern work. Journal of Organizational Behavior, 23, 383-400.

Bakker, A.B. (2008). The work-related flow inventory: Construction and initial validation of the WOLF. Journal of vocational behavior, 72, 400-4I4.

Bakker, A.B. \& Demerouti, E. (2007). The Job Demands-Resources model: state of the art. Journal of Managerial Psychology, 22, 309-328.

Bakker, A.B., Demerouti, E. \& Verbeke, W. (2004). Using the Job Demands-Resources model to predict burnout and performance. Human Resource Management, 43, 83-104.

Bakker, A.B. \& Geurts (2004). Toward a dual-process model of work-home interference. Work and Occupations, 3I, 345-366.

Baron, R.M. \& Kenny, D.A. (I986). The moderator-mediator variable distinction in social psychological research: Conceptual, strategic, and statistical considerations. Journal of Personality and Social Psychology, 5I, II73-II82.

Beffers, T. \& Van den Brink, I. (2008). Telewerken; Samenvatting van resultaten. Gedownload op I8-7-2008 van www.fnv.nl.

Boxall, P. \& Purcell, J. (2003). Strategy and Human Resource Management. Basingstoke: Palgrave Macmillan.

Csikszentmihalyi, M. (1992). Flow. The psychology of happiness. London: Rider.

Demerouti, E., Taris, T.W. \& Bakker, A.B. (2007). Need for recovery, home-work interference and performance: Is lack of concentration the link? Journal of vocational behavior, 7I, 204-220.

Field, A. (2009). Discovering statistics using SPSS (and sex and drugs and rock ' $n$ roll). 3 rd fully updated edition. London/Thousand Oaks/New Delhi: Sage Publications.

Fouarge, D., Grim, R., Kerkhofs, M., Roman, A. \& Wilthagen, T. (2004). Trendrapport Aanbod van Arbeid. Tilburg: OSA.

Gajendran, R.S. \& Harrison, D.A. (2007). The good, the bad, and the unknown about telecommuting: meta-analysis of psychological mediators and individual consequences. Journal of Applied Psychology, 92, I524-1541.

Gareis, K. (2003). The intensity of telework in 2002 in the EU, Switzerland and the US. Paper presented at the International Congress New Work 2002, Sustainability in the new economy: Designing a new work space. Sustainability and ethical dimensions, September 3-5, 2002, in Badajoz, Spain. Gedownload op 20-5-2004 van www.sibis-eu.org.

Golden, T.D. (2006). Avoiding depletion in virtual work: Telework and the intervening impact of work exhaustion on commitment and turnover intentions. Journal of vocational behavior, 69, 176-87.

Isen, A (2000). Positive affect and decision making. In M. Lewis \& J. Haviland-Jones (Eds.), Handbook of emotions (pp. 4I7-435). New York: Guilford Press.

Karasek, R. (1985). Job content instrument: Questionnaire and user's guide, revision I.I. Los Angeles: University of Southern California.

Kolb, D.G. \& Collins, P.D. (2009). Managing creativity and innovation through team connectivity and individual choice. Paper presented at the $25^{\text {th }}$ EGOS Colloquium, Barcelona, 2009.

Kumar, P. (2000). Rethinking High-Performance Work Systems. Current Issues Series. Kingston: Industrial Relations Centre, Queen's University. Gedownload op 15 april 2008 van www.busi.mun.ca/shart/6320/readings/kumar.pdf.

Kurland, N.B. \& D.E. Bailey (I999). Telework: The advantages and challenges of working here, there, anywhere, and anytime. Organizational Dynamics, 28, 53-68.

Kurland, N.B. \& Cooper, C.D. (2002). Manager control and employee isolation in telecommuting environments. Journal of High Technology Management Research 13, 107I26.

Mann, S. \& Holdsworth, L. (2003). The psychological impact of teleworking: stress, emotions and health. New Technology, Work and Employment, I8, I96-2II. 
Mokhtarian, P.L., Bagley, M.N. \& Salomon, I. (1998). The impact of gender, occupation and presence of children on telecommuting motivations and constraints. Journal of the American Society for Information Science, 49, III5- II34.

Montreuil, S. \& Lippel, K. (2003). Telework and occupational health: a Quebec empirical study and regulatory implications. Safety Science, 4I, 339-358.

Nilles, J.M. (1998). Managing telework. Strategies for managing the virtual workforce. New York: John Wiley and Sons.

Peters, P., Den Dulk, L. \& De Ruijter, J. (20I0). May I work from home? The multidimensional character of the employment relationship as signalled in managers' telework attitude formation processes. Special issue. Equality, Diversity and Inclusion. In druk.

Peters, P., Den Dulk, L. \& Van der Lippe, T. (2009). The Effects of Time-Spatial Flexibility and New Working Conditions on Employees'Work-Life Balance: The Dutch Case. Special issue. Community, Work E' Family, I2, 279-298.

Peters, P., Bleijenbergh, I. \& Oldenkamp, E. (2009). The telework adoption process in a Dutch and French subsidiary of the samen ICT-multinational: how national culture and management principles affect the success of telework programs. The Journal of E-Working, 3, pp. I-I6.

Peters, Pascale \& Stefan Heusinkveld (2008). Telewerken als HR missie. Personeelbeleid, 44 (6): I6-19.

Peters, P. \& Van der Lippe, T. (2007a). The Time Pressure Reducing Potential of Telehomeworking: The Dutch Case. International Journal of HRM, I8, 430-47.

Peters, P. \& Van der Lippe, T. (2007b). Access to home based telework: a multilevel and multi-actor perspective. In T. van der Lippe \& P. Peters (Eds.), Competing Claims in Work and Family Life (pp. 233-248). Cheltenham: Edward Elgar.

Peters, P., Tijdens, K.G. \& Wetzels, C. (2004). Employees' opportunities, preferences, and practices in telecommuting adoption. Information \& Management, $4 I, 469-482$.

Peters, P. \& Batenburg, R. (2004). Dilemma's in het thuiswerkbeleid van Nederlandse bedrijven: Nieuwe punten voor de HRM-agenda. Tijdscbrift voor HRM, 3, 25-48.

Petty, M., McGee, G. \& Cavender, J. (1984). A Meta-Analysis of the Relationship Between Individual Job Satisfaction and Individual Performance. Academy of Management Review, 9, 712-721.

Salanova, M., Bakker, A.B. \& Llorens, S. (2006). Flow at work: evidence for an upward spiral of personal and organisational resources. Journal of Happiness Studies, 7, I-22.

Schaufeli, W.B. \& Van Dierendonck, D. (200I). Utrechtse Burnout Schaal (UBOS): Psychodiagnostisch gereedschap. De Psycholoog, 36(I), 9-I2.

Scheeres, K. \& Bakker, A.B. (2003). Flow bij muziekdocenten en hun leerlingen: de aanstekelijkheid van piekervaringen. Gedrag E Organisatie, 16, 23-38.

Taskforce Mobiliteitsmanagement. Voorstel Taskforce Mobiliteitsmanagement. 8 september 2008. Gedownload op 8 oktober 2008 van www.tfmm.nl/documenten/29.pdf.

Veldhoven, M. van \& Meijman, T. (1994). Het meten van psychosociale arbeidsbelasting met een vragenlijst: De Vragenlijst Beleving en Beoordeling van de Arbeid (VBBA). Amsterdam: Nederlands Instituut voor Arbeidsomstandigheden.

Vittersø, J., Akselsen, S., Evjemo, B., Julsrud, T.E., Yttri, B. \& Bergvik, S. (2003). Impacts of home-based telework on Quality of Life for employees and their partners. Quantitative and qualitative results from a European survey. Journal of Happiness Studies, 4, $20 \mathrm{I}-233$.

Van Klaveren, M., Tijdens, K., Peters, P. \& Wetzels, C. (2005). IT and telework. In B. Peper, A. van Doorne-Huiskes \& L. den Dulk (Eds.), Flexible Working and Organisational Change. The Integration of Work and Personal Life (pp. 268-293). Cheltenham: Edward Elgar.

Van der Lippe, T. \& Glebbeek, A. (2004). Inleiding. Tijdschrift voor Arbeidsvraagstukken, 20, $5-7$.

Van Ruysseveldt, J., Smulders, P. \& Taverniers, J. (2008). De invloed van werkeisen en hulpbronnen op uitputting en bevlogenheid. Tijdschrift voor Arbeidsvraagstukken, 24, 226-243. 
Van Ruysseveldt, J., Taverniers, J. \& Smulders, P. (2009). Onderzoeksnotitie: De voorspelling van werkstress in Nederland en Vlaanderen. Tijdschrift voor Arbeidsvraagstukken, 25, 97-Io9.

Walrave, M. (2005). Telewerken: waarom en hoe opstarten in uw organisatie? In Handleiding anders werken voor managers en werknemers die willen starten met telewerk (pp. 23-38).

Brussel: Markant VZW. Gedownload op 2I december 2006 van www.tijdvoortelewerk.be.

Wright, T.A. \& Cropanzano, R. (1998). Emotional exhaustion as a predictor of job performance and voluntary turnover. Journal of Applied Psychology, 83, 486-493.

\section{Noot}

1. De auteurs danken professor dr. Arnold Bakker van de Erasmus Universiteit Rotterdam voor zijn bijdrage aan de ontwikkeling van de vragenlijst en de reviewers en de editor voor de stimulerende feedback op eerdere versies van deze bijdrage.

Telework as a job resource: A comparison of 'flow' and exhaustion among marginal and substantial teleworkers

P. Peters \& M.W. Wildenbeest, Gedrag \& Organisatie, volume 23, June 2010, nr. 2, pp. 97-117

This cross-sectional study among 331 teleworkers aimed to contribute to the contemporary telework debate on the importance of the telework frequence for telework outcomes by examining whether employees who telework more than one day per week on average ('substantial teleworkers') experience more work-related flow and less exhaustion than employees who telework less than one day per week on average ('marginal teleworkers'). Employing the 'Job Demands-Resources model', the study considered particularly substantial telework a job resource, and looked into the direct and indirect relationships between 'substantial telework' and the two outcome variables. Employing multivariate regression analyses, empirical support was found for the proposition that substantial telework is associated with more flow. Remarkably, this was particularly felt when employees were interrupted more frequently in their home offices. Moreover, particularly teleworkers who reported frequent overtime and more job autonomy expressed lower exhaustion levels when they teleworked substantially than when they teleworked marginally. Whether these outcomes also hold for other worker categories, such as lower educated employees, requires further investigation.

Key words: telehomework, New Ways to Work, job resource, flow, exhaustion 